これらの吸着等温変化から BET 法により吸着水分子 が表面に笚分子層を形成するときの相対湿度を求める と、いずれも20 30\%の值が得られる。さらに水分子の 断面積加吸着による表面積を求め, 見かけの幾何学的 表面積との比をとると処理による浸食の浅いもので 30 倍, 墚いもので 500 倍近い值が得られる。これはきわ めて大きな值である。

表面処理により単にフッ素原子がとられるだけと仮定 し, 処理による減量加らン素原子の穴の面積を求め, 水に対する吸着表面積との比を求めるとおおよそ10 20 倍程度になる。したがって脱フッ反応の行なわれた 場所が必ず水の吸着坐席になっているわけではなく、 フ 孪原子の断面積との比からその 1/3 1/6 程度が吸着 坐席になっている。換言すればフッ素原子が数個とれ て，一つの水に対する吸着坐席ができることになる。

生の PTFE の吸着坐席はきわめてパラパラの状態に 分散している不純物の塩と考えられている"。表面処理 の場合も坐席の内容は異なるが, 比較的分散して存在す ることが考えられる。

\section{5 吸湿の処理時問による効果}

同じ処理液で処理時間を変えた試料がどのように吸着 坐席を増大するかを知るため, 一連の試料で吸湿量を一 定相対圧のもとで測定した。これを Fig. 7 に示す。SNT
法では処理減量の変化と同じよらに吸湿量の変化は認め られないが, SA 法では処理減量に対応し直線的に吸湿 量が増大していることが認められる。これらのことから $\mathrm{SA}$ 法で処理したときの吸着坐席は初期にできたものと 同じ吸着能をもち, その坐席が処理時間の増大により順 次増加してくることが推定できる。

このようにして吸着坐席を増加し, 前に述べたように 表面積を增大しても, 吸湿等温変化の高相対圧で吸湿量 の急上昇がみられない。これは毛管凝縮のないことであ るから，したがって SA 法で処理した試料は吸着坐席 が増加していても，処理面に小さな毛管ができていない ことを示すものである。

付記：「高分子と水の討論会」昭和 33 年 11 月 22 日に 一部を発表。

\section{文献}

1) “TEFLON" Treatment for Bonding: Du Pont Information Bulletin No. x-75

2) D. R. Nelson, T. J. Kilduff and A. A. Benderly: Ind. Eng. Chem., 50, 329(1958)

3) 矢野泰：実験化学講座，8, 125(1957)

4) J. J. Chessick, F. H. Healey and A. C. Zettlemoyer: J. Phys. Chem., 60, 1345(1956)

\title{
On the Surface Properties of Surface-Treated Polytetrafluoroethylene
}

\section{Treating Methods and Water Vapour Adsorption by Treated Specimen}

\author{
By Yosiyasu Sekita* and Koji Kawasaki*
}

\begin{abstract}
The sodium-naphthalene-tetrahydrofuran method and the sodium-liquid ammonia method have been used for the surface treatment of polytetrafluoroethylene. For various specimens treated by the two method adsorption isotherms of water vapour and weight loss were measured. It has been found that in the former method the reaction takes place only at the surface layers, but in the latter case the reaction proceeds into the interior of the polytetrafluoroethylene samples, and the adsorption site for water vapour and the weight loss of the sample increase linearly with treated time.
\end{abstract}

第 2 報 ポリ四フッ化エチレンとその表面処理面の水に対する接触角 (1960 年 12 月 10 日受理)

関田吉泰・川崎弘司

\footnotetext{
要 旨 ポリ四フッ化エチレンの未処理面㧍よびナトリウムーナフタリンーテトラヒドロフラン法とナト リウムー液安法による処理面の水に対する接触角を液滴法で測定した。未処理切削面の接触角は切削方向と平
} 
行で $108^{\circ}$ ，垂直方向で $115^{\circ}$ であった。ナトリウムーナフタリン法による処理面は $52^{\circ}$ の比較的安定な接触 角を処理条件を変えても示すのに反して，ナトリウムー液安法ではそれらの処理条件によって変化する接触角 が得られる。これらの差は吸着坐席の分布状態と表面におけるあらさが関係しているよらである。

\section{1. 緒言}

第 1 報1)ではポリ四フッ化エチレン (PTFE) の表面 処理にナトリウムーナフタリンーテトラヒドロフラン法 (SNT 法) およびナトリウムー液安法（SA 法）を使用 し，その処理状態を吸湿特性の面から調へ，両者の表面 処理には著しい差異のあることを指摘した。すなわち前 者で㳔処理が表面層で終り, 後者は処理時間によって深 く脱フッ反応が行なわれる。ここでは上述の二つの方法 による処理表面の相違を接触角の変化から観察した。

\section{2. 実験方法}

\section{1 試 料}

試料は第 1 報と同様, 日本バルカー社の PTFE で, その厚さは $0.1 \mathrm{~mm}$ から $1 \mathrm{~mm}$ までの切削フィルムを 使用した。熱処理試料については空気中電気炉内で生の 試料に所要の熱処理を行なったものである。表面処理面 は切削フィルムおよび熱処理面に第 1 報で述べた表面処 理を行なったものである。

\section{2 接触角の测定}

接触角の測定には液滴法を用いた。毛管により微小水 滴を試料表面に付着させ，その水滴を側面から低倍率顕 微鏡で撮影する。その写真から幾何学的に接触角を求め る。この場合, 撮影直前さらに微小水滴を加えたときの 接触角を前進接触角 $\theta_{a}$ ，毛管により表面の水滴から液 を吸引し液滴面がぬれ面よりきわめてわずか後退したと きの接触角を後退接触角 $\theta_{r}$ とする。一つの試料面につ いて 4 回測定を行ない, その平均值を各々の接触角とし て表示した。列については測定の重点を执かなかった ので, 特に $\theta_{r}$ の注意書きのない接触角はすべて $\theta_{a}$ を 示すものとする。

接触角の測定の際にその表面の処置は次のようにす る。末処理面はアルコール-四塩化炭素-蒸留水洗浄一風 乾を行ない，表面処理後はアセトンーテトラヒドロフラ ン一蒸留水洗浄一風乾を行なう。接触角は空気中のごみが 表面に付着すると変動するので注意が必要である。

\section{3. 実験結果および考察}

\section{1 末処理 PTFE 面の接触角}

処理面の接触角を謂べるためには，まず末処理面の接 触角について知らなくてはならない。PTFE 表面の水に 対する接触角についてはすでに多くの報告がある2) これらによると平らな表面の接触角は 102 114の範囲 内にある。また表面が平らでないときには表面の形状に より接触角が変化し，このため切削面では加工きずの方
向により接触角に差が生じることが示されている゙。

われわれの未処理面における実験結果にはそれらと同 様の結果が得られている。まずわれわれが使用した切削 面の接触角を Table 1 に示す。この結果から切削加工の さいに PTFE 表面にできる平行きず(条痕)に垂直方向 と平行方向では接触角が異なることがわかる。この中で 条痕に平行方向の前進接触角の $108^{\circ}$ の值は特に表面の 平滑化に注意をはらって测定した Zisman らの結果2),31 とほぼ一致する。したがって条痕に平行方向の断面では 表面の凹凸が少なく，その表面のあらさが接触角に影響 を与えない程度のものであることがわかる。

Table 1 Contact angles of distilled water on skired polytetrafluoroethylene film at $24^{\circ} \mathrm{C}$ and $60 \%$ relative humidity.

\begin{tabular}{l|c|c}
\hline \hline Direction of spreading & $\begin{array}{c}\text { Advancing } \\
\text { contact angle } \\
\left(\theta_{a}\right)\end{array}$ & $\begin{array}{c}\text { Receding } \\
\text { contact angle } \\
\left(\theta_{r}\right)\end{array}$ \\
\hline $\begin{array}{l}\text { Parallel to the grooves } \\
\text { Perpendicular to the } \\
\text { grooves }\end{array}$ & $108^{\circ}\left( \pm 2^{\circ}\right)$ & $64^{\circ}\left( \pm 8^{\circ}\right)$ \\
\hline
\end{tabular}

\section{2 表面処理面の接触角}

第 1 報で報告したように SNT 法では PTFE 表面で 表面処理がとまり SA 法では末面処理が内部まで行な われることを示したが，この処理の状態の差異を接触角 から調べる。

\subsubsection{SNT 法}

\subsection{1-a どこから表面処理が行なわれるか}

SNT 法による表面処理では未処理切削面を一定時間 以上処理液に浸して後, 洗浄すれ接触角 $52^{\circ}$ の一定し た表面処理面が得られる。この場合， $52^{\circ}$ の接触角を示 す表面処理面をつくるに必要な最小限の処理液に浸す時 間(処理時間) は処理液の不純物の程度によって变わる。 たとえば処理液作成に必要なテトラヒドロフランとして 試薬特級を使用した処理液では 5〜6秒程度処理すれば よく, 試薬 1 級を使用したときには 60 秒程度必要とな る。今その接触角 $52^{\circ}$ を示す一定試料が得られる以前 のきわめて初期の処理変化について調べてみる。

まずテトラヒドロフランに試薬 1 級を使用した処理液 を作成する。次に末処理 PTFEに熱処理を行ない結晶 化度を変えた PTFE をつくる5)。これらの結晶化度は 赤外線スペクトルによって決める ${ }^{6)}$ 。これらの結晶化 PTFE 面を液体空気で十分冷却し, 表面のあらい面を けずり取って平らにする。これらの結晶化度の異なる面 を上述の処理液に同時に浸し，1 分間以内に同時に引き 
上げて表面処理試料をつくる。これらの未処理試料の結 晶化度とその処理面の接触角の関係は結晶化度の大きい ほど接触角が大きくなる傾向を示している。たとえば SNT 法 30 秒程度の処理で未処理面の結晶化度 $50 \%$ のものが表面処理後 $52^{\circ}$ の接触角を示すのに反し, 結晶 化度 $60 \%$ のものを処理した表面では $70^{\circ}$ の高い接触角 を示している。このように結晶化度の高い試料も 1 分程 度以上処理すれば $52^{\circ}$ の接触角を示す処理面になる。こ のような傾向は処理液の疲労した SA 法の処理面でも 認められる。これらの実験結果から処理時間が一定の接 触角を示すほど十分でないときには, 結晶化度の大きい ほど表面処理のされ方が遅くなっていることがわかる。

\section{2. 1-b SNT 法表面処理と接触角の变化}

SNT 法で処理時間 1 分以上 200 時間程度の範囲の変 化について述べる。この間の処理時間の表面処理面では 条痕方向の前進接触角はほとんど変わらず $52^{\circ}$ の接触 角を示す。これは第 1 報で表面処理による処理減量㧍よ び吸湿特性が処理時間の増大によって変わらないことと 対応している。相当長時間処理しても条痕方向による接 触角の方向特性は未処理面と同様に存在する。これは表 面処理により，表面のあらさが末処理面と比較して大き く変わらないことが推定できる。すなわち SNT 法は表 面のあらさに大きな変動を与えず, 処理が表面層で行な われることがいえる。

\subsection{SA 法}

\section{2. 2-a SA 法による処理面の処理時間による接触角 の変化}

$\mathrm{SA}$ 法低温 $\left(-78^{\circ} \mathrm{C}\right)$ 処理で処理面の一例は Table 2 に示すような值になる。 $\mathrm{SA}$ 法処理では 2 3 秒程度の

Table 2 Contact angles of distilled water on treated polytetrafluoroethylene by sodiumammonia process at $-78^{\circ} \mathrm{C}$.

\begin{tabular}{|c|c|c|c|c|}
\hline $\begin{array}{l}\text { Sample } \\
\text { No. }\end{array}$ & $\begin{array}{l}\text { Treated } \\
\text { time } \\
(\mathrm{min})\end{array}$ & $\begin{array}{l}\text { Direction } \\
\text { of } \\
\text { spreading }\end{array}$ & \multicolumn{2}{|c|}{$\begin{array}{cc}\theta_{a} & \theta_{r} \\
\text { (degree) } & \text { (degree) }\end{array}$} \\
\hline 1 & 1 & $\begin{array}{l}\text { Parallel } \\
\text { Perpendicular }\end{array}$ & $\begin{array}{l}73( \pm 4) \\
87\end{array}$ & $\begin{array}{l}0-33 \\
0\end{array}$ \\
\hline 2 & 20 & $\begin{array}{l}\text { Parallel } \\
\text { Perpendicular }\end{array}$ & $\begin{array}{l}73( \pm 8) \\
90\end{array}$ & $\begin{array}{l}0 \\
0\end{array}$ \\
\hline 3 & 50 & $\begin{array}{l}\text { Parallel } \\
\text { Perpendicular }\end{array}$ & $\begin{array}{l}74( \pm 7) \\
91\end{array}$ & $\begin{array}{l}0 \\
0\end{array}$ \\
\hline 4 & 1200 & $\begin{array}{l}\text { Parallel } \\
\text { Perpendicular }\end{array}$ & $\begin{array}{l}100( \pm 5) \\
102\end{array}$ & $\begin{array}{l}0 \\
0\end{array}$ \\
\hline
\end{tabular}

処理時間でその処理温度による一定な接触角を示す処理 面が得られる。処理時間の短い範囲は SNT 法処理面と 同じように条痕方向により異なる接触角を示す。しかし 処理時間をきわめて增大すると順次条痕方向による接触

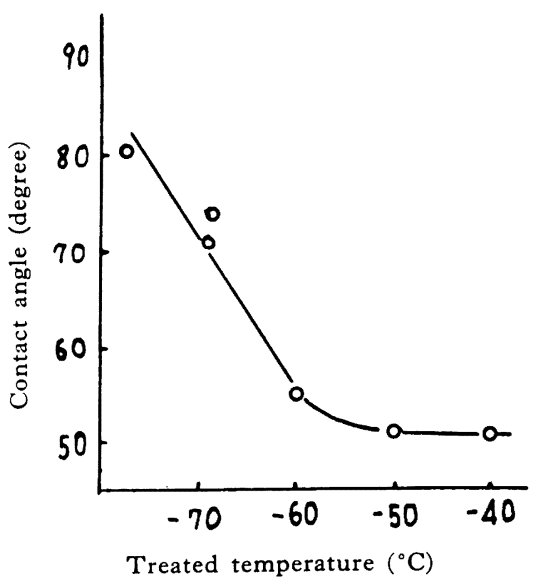

Fig. 1. Variation of contact angle on PTFE film treated for $1 \mathrm{~min}$. by the sodium-liquid ammonia process with treated temperature.

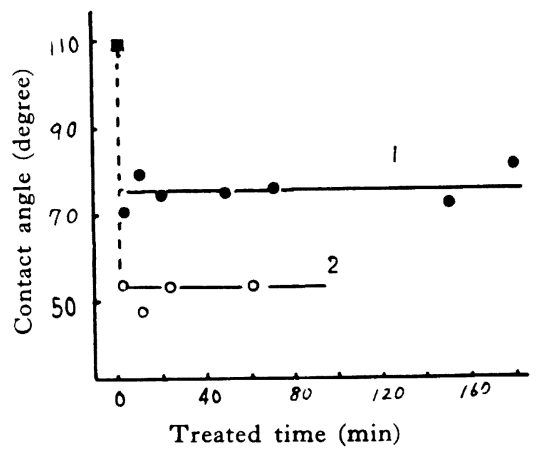

: Untreated

: Treated by the sodium-liquid ammonia process (SA process) at $-78^{\circ} \mathrm{C}$

$\bigcirc$ : Treated by the SA process at $-60^{\circ} \mathrm{C}$

Fig. 2. Variation of contact angle with treated time for PTFE film. Treated by sodium-liquid ammonia.

角の差が消失する。これは処理時間が増すと末処理面の もつあらさを越える大きなあらさ変化があるためと思わ れる。

SA 法 1 分間表面処理で処理温度を変えたときの接触 角の変化は Fig. 1 のような傾向になり, その各々の処 理温度で処理時間を変化させたときの接触角の変化の 1 例は Fig. 2 に示される。Fig. 2-1 は金属ナトリウム 1.5 重量 \%を無水アンモニア中に溶解させ $-78^{\circ} \mathrm{C} て ゙$ 表面処理をした場合の変化であり, Fig. 2-2 はその濃 度の処理液で $-60^{\circ} \mathrm{C}$ で処理した場合の水に対する接触 角の変化である。Fig. 2 の変化は接触角の変化しない 処理時閒数十分程度を中心とする変化であるが，処理時 間を十分増加すると接触角はしだいに増大する。たとえ 
ば $\mathrm{SA}$ 法 $-78^{\circ} \mathrm{C}$, 処理時間 1 時間以内の処理では接触 角が $73^{\circ}$ であったものが, 20 時間程度処理すると接触 角は $100^{\circ}$ に增大する。

これらの変化をまず考えてみる。第 1 報において SA 法による処理面では表面処理による処理減量および吸湿 特性が処理時間の増大により直線的に増加することを示 した。水に対する吸着坐席が増加するといらことは，こ れらの坐席がすべて表面だけに分布していると仮定すれ ば, 処理時間の増大により比表面エネルギーを増大し接 触角を低下させなくてはいけない。これは処理時間の増 大によって接触角は一定または増大するという実験事実 に反する。したがって処理時間の増大により吸着坐席が 表面的でなく体積的に分布していることがまず考えられ る。

\section{2. 2-b SA 法による妈理膜}

この体積的な分布は処理された厚さを測定することに よって確認できる。表面処理をすると PTFE はフッ素 原子をとられて減量する。この処理面を垂直にミクロト 一ムで切って顕微鏡で調べると末処理 PTFE の上にあ る厚さの褐色に変色した表面処理膜がみえる。この表面 処理膜は脱フッのあとの炭素主鎖に関倸していると思え るが，厚さが一様でなく場所により厚くなったり薄くな ったりしている。これらの表面処理による処理減量と表 面処理膜自体の厚さの分布は Fig. 3 のようになる。こ のよらに処理膜の厚さに変化のあることから SA 法で は吸着坐席が単に体積的に分布するだけでなく局部的に

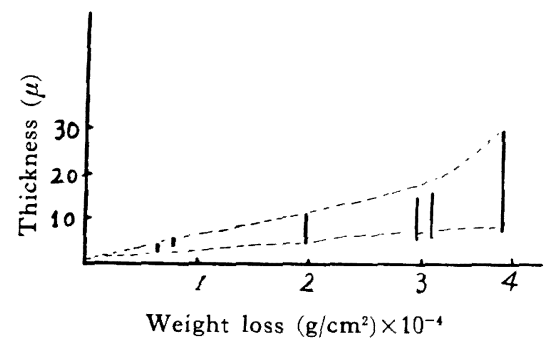

Fig. 3. Variation of thickness of the surface layer treated by the sodium-liquid-ammonia process with weight loss.
処理が行なわれていることがわかる。これは表面をあら さ計で測定すると処理減量の大きいものほどあらさが増 大していることと対応している。

\section{3 表面のあらさと接触角}

$\mathrm{SA}$ 法処理では表面のあらさ変化がある。それがどの ような影響を及ぼすかを調べてみる。

まず切削 PTFE 面を融点付近まで熱するとその表面 は冷却速度の遅いものほどあらさを増大した自由表面が 得られる。これらの自由表面の水に対する接触角はあら さ增大によって増加しており，それらの自由表面をSNT 法で十分処理した場合も表面のあらさ増大によって接触 角は増大している。これらの熱処理条件および接触角の 変化を Table 3 に示す。

さらにこの実験值からあらい面では平らな面の接触角 と比較し未処理面では $108^{\circ}$, 表面処理面では $52^{\circ}$ の值 から大きく増大している。したがって表面処理面に掠い ても表面のあらさ増大によって接触角が増大することが 確認できる。

ここであらさ変化を中心とした接触角の変化につけて 考えてみよう。SNT 法および SA 法短時間処理の場合 は表面のあらさ変化はないと考えられるので接触角の未 処理面からの低下はすべて比表面エネルギーの増大だけ で解釈できる。しかし SA 法では処理時間の增大によ り表面のあらさを増大してくる。これは接触角を增大さ せる効果を与えるが，処理時間の増大によって表面にも 順次吸着坐席を増し接触角を低下させるのでこの二つが 互に補償しあって, ある処理時間の範囲は一定な接触角 を示すものと考えられる。さらに長時間処理すると表面 での吸着坐席の数は飽和值に達し, 比表面エネルギーは 変わらずあらさ増大だけが影響を及ぼすので接触角は増 大してくるものと解せられる。

付 記：本研究の大要は「高分子と水の討論会」昭和 34 年 11 月 6 日で発表した。

\section{文献}

1) 関田吉泰, 川崎弘司: 高化投稿中

2) H. W. Fox and W. A. Zisman: J. Colloid Sci., 5, $514(1950)$

Table 3 Contact angles of distilled water on heat treatad polytetrafluoroethylene and the surfaces of them treated by the sodium-naphthalene-tetrahydrofuran process.

\begin{tabular}{c|c|c|c|c}
\hline $\begin{array}{c}\text { Sintering temp. } \\
\left({ }^{\circ} \mathrm{C}\right)\end{array}$ & $\begin{array}{c}\text { Sintering time } \\
(\mathrm{hr})\end{array}$ & $\begin{array}{c}\text { Cooling rate } \\
\left({ }^{\circ} \mathrm{C} / \mathrm{min}\right)\end{array}$ & Contact Angle \\
\hline 370 & 1 & Ice water quenched & 128 & 74 \\
370 & 1 & 1.00 & 135 & 88 \\
370 & 1 & 0.25 & 142 & 100 \\
\hline
\end{tabular}


3) M. K. Bernett and W. A. Zisman : J. Phys. Chem., 63, 1241(1959)

4) A. J. G. Allan and Roberts: J. Polymer Sci., 39, 1(1959)
5) P. E. Thomas, J. F. Lontz, C. A. Sperati and J. L. McPherson: SPE Journal, 12, 89(1956)

6) R. E. Moynihan: J. Am. Chem. Soc., 81, 1045 (1959)

\title{
On the Surface Porperties of Surface-Treated Polytetrafluoroethylene
}

\author{
II. Contact Angles of Water Drops on Untreated and \\ Treated Polytetrafluoroethylene Eilms \\ By Yosiyasu Sekita* and Koji Kawasaki*
}

\begin{abstract}
The wettability of polytetrafluoroethylene was studied from the measurements of the contact angle by the drop method for the untreated and treated films by the sodium-naphthalenetetrahydrofuran and the sodium-liquid ammonia. The contact angle of water on the films skived for practical use depends on the direction of spreading, the advancing contact angle measured in the direction perpendicular to the grooves is $115^{\circ}$ and that in the direction parallel to the grooves is $108^{\circ}$.

The contact angle has the constant value approximately $52^{\circ}$ on the surface treated by the sodium-naphthalene-tetrahydrofuran for various conditions of the treatment, but on the surface treated by sodium-liquid ammonia the contact angle depends considerably upon the conditions of the treatment, especially upon the treated time and the treated temperature.

This difference seems to be attributable to the differences in the distribution of the adsorption sites for water molecules and the surface roughness.
\end{abstract}

* Electrotechnical Laboratory (Nagatacho, Tokyo) 